\title{
Evaluation of Indonesian Navy Information Technology Governance Using Cobit 5
}

\author{
Aria Cakra Wibawa ${ }^{1}$, Bambang Suharjo ${ }^{2 *}$ \\ ${ }^{1}$ Indonesian Navy Information and Data Processing Services, Indonesia \\ ${ }^{2}$ Mathematics Department, Universitas Pertahanan, Indonesia \\ *Corresponding author.Email: bambang_suharjo@tnial.mil.id
}

\begin{abstract}
In carrying out its duties, the Indonesian Navy uses a lot of Information Technology. Especially at this time during the last year was the Covid-19 Pandemic, the use of Information Technology has been increasing massively. Therefore, it is necessary to conduct an evaluation to determine the achievement of its capabilities and to obtain improvements that need to be made to make it even better. This study uses a mixed method that combines quantitative and qualitative research to evaluate the IT capabilities of the Indonesian Navy with the Cobid 5 method. Respondents and research subjects used are officers of the Indonesian Navy's Information and Data Processing Service. The attainment result of IT capabilities in the Indonesian Navy reaches a good level with 2 domains reaching level 4 and 3 domains reaching level 3. This is driven by the use of IT in times of an increasingly high pandemic so that IT performance in the Indonesian Navy is forced. just getting better. Besides that, there are 13 dimensions that require treatment to increase its capabilities.
\end{abstract}

Keywords: Cobid 5, Information System Governance, Indonesian Navy

\section{INTRODUCTION}

The challenges faced by the Indonesian Navy in carrying out their duties are getting bigger. In accordance with the Republic of Indonesia Law Number 34 of 2004 concerning the Army, it is the duty of the Navy to maintain national sovereignty and security at sea.

In carrying out its duties, the Indonesian Navy uses a lot of Information Technology. Especially at this time during the last year was the Covid-19 pandemic, the use of Information Technology has been increasing massively. Based on research, it shows that the use of Information Technology in a pandemic is getting higher with an increasingly important role [1].

Based on this background, it is necessary to evaluate in order to know the maturity achievement and the recommendations that can be given. This is of course important for better IT performance.

The use of Cobid 5 has proven to be widespread and yields good maturity analysis and recommendations for improvement and progress. Several agency studied examining IT maturity and capability yield good calculations and useful recommendations [2], [3]. Previous research on IT maturity in the Indonesian Navy using COBID 5 also provided useful maturity calculations and recommendations [4], although it is needed to be done continuously and made improvements.

Based on the above discussion, the research question is how to evaluate information system using Cobid 5 in the Indonesian Navy and how the recommendations can be given so that information system maturity in the Indonesian Navy is better, and is able to answer the challenges the tasks.

\section{LITERATURE REVIEW}

Evaluation is a management step to improve the organization. The form of evaluation carried out in the IT field uses an audit system. In the IT field, COBIT is used to conduct systematic capability and maturity audits [5]. More than that, information system audits can strengthen financial system audits. Thus, an information system audit is very important to do today [3]. 
COBIT is a standard that is considered complete with comprehensive coverage as an audit framework and can be used in various types of organizations. COBIT 5 is a business framework for an IT governance framework, as well as a collection of tools that support managers to bridge the gap between control requirements, technical issues and business risk. COBIT 5 is a framework for governance and management of information technology and all that is related, starting from meeting the needs of stakeholders for information and technology. COBID 5 include five domains, such as: (1) align, plan, organize (APO), (2) build acquire, implement (BAI), (3) delivery, service and support (DSS), (4) monitor, evaluation and assess (MEA), and (5) evaluate, direct and monitor (EDM). COBIT 5 uses 5 levels of capability model. [6] The levels in the Capability Model are:

1) Level 0: namely Incomplete Process

2) Level 1: Performed Process

3) Level 2: Managed Process

4) Level 3: Established Process

5) Level 4: Predictable Process

6) Level 5: Optimizing Process

Previous researches used COBID 5 to evaluate IT in many fields of organizations, such as: military especially in Navy [4], business [7], government institution such as Central Statistics Agency [8] and National Library [9], education especially a University [10]. The results are able to show the diverse of IT capability levels of each organization, from the level of maturity / capability low (1) to high (4). Especially in Navy, result of capability still lower than 3 (established process), in the 2017. It show that need to be given some treatments. After three years, it need to be evaluated again.

Furthermore, the recommendations submitted vary according to the institution and the most important thing is that these recommendations are very useful for increasing their capabilities.

\section{METHODS}

This research used mixed method. It was a descriptive quantitative study to obtain an IT maturity score and is equipped with qualitative explanations for indicators that require improvement [11]. The number of sampling is a number of 22 Information and Data Processing Services officers and research subjects who will be interviewed a number of 5 Information and Data Processing Services Intermediate Officers. The research steps were carried out starting from the preparation of questionnaires and interview guides, determining respondents and research subjects, data collection with questionnaires followed by validity and reliability tests and then IT capability analysis and continued with interviews to get an explanation of IT maturity and finally formulating recommendations. In entirely, the research steps can be described in the flowchart, as Figure 1.

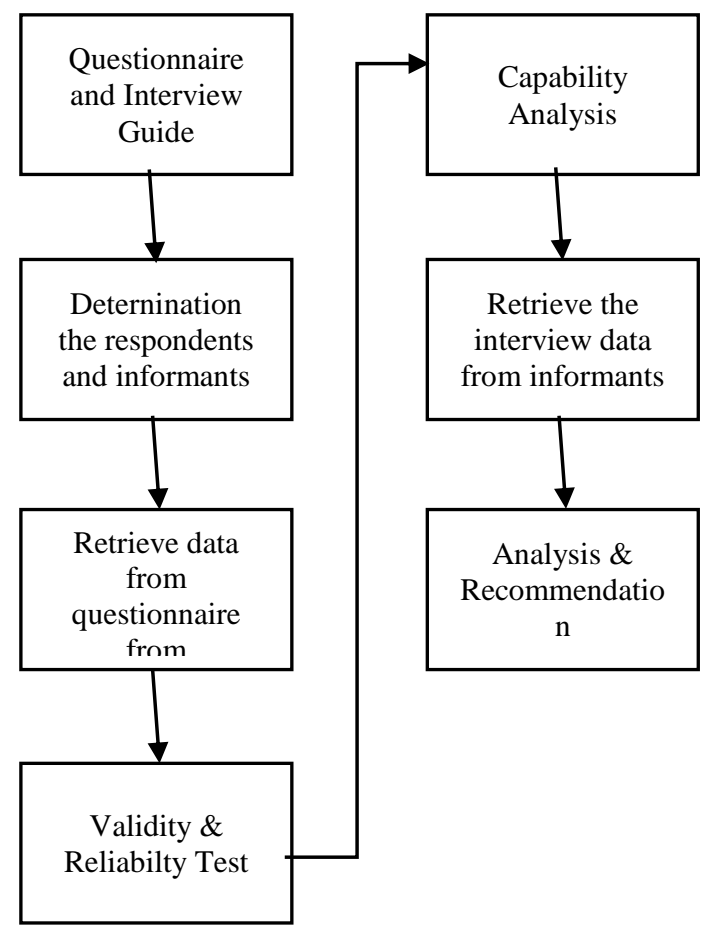

FIGURE 1. RESEARCH FLOWCHART

\section{RESULT AND DISCUSSION}

Based on the results of the questionnaire submitted to the respondents, 52 data were obtained with some averages according to their respective domains. There are 5 groups of domains according to the information system evaluation process, include: (1) Align, Plan, organize (APO), (2) build acquire, implement (BAI), (3) Delivery, Service and Support (DSS), (4) Monitor, Evaluation and Assess (MEA), and (5) Evaluate, Direct And Monitor (EDM).

\section{a. Align, Plan, Organize (APO)}

The results of the questionnaire that have been filled were followed by descriptive calculations with an average. The results obtained from each dimension in the APO domain were presented in table 1 . 
TABLE 1. AVERAGE SCORE OF EACH DIMENSION IN APO DOMAIN

\begin{tabular}{llc}
\hline Code & \multicolumn{1}{c}{ Dimension } & $\begin{array}{c}\text { Average } \\
\text { Score }\end{array}$ \\
\hline APO01 & $\begin{array}{l}\text { Manage the IT } \\
\text { Management Framework }\end{array}$ & 3.1 \\
APO02 & $\begin{array}{l}\text { Manage Strategy } \\
\text { APO03 }\end{array}$ & 3.1 \\
& Manage Enterprise & 3.6 \\
Architecture & \\
APO04 & Manage Innovation & 3.7 \\
APO06 & Manage Portfolio & 3.5 \\
APO07 & Manage Budget and Costs & 3.5 \\
APO08 & Manage Relationships & 3.3 \\
APO09 & Manage Service & 3.5 \\
& Agreements & 3.5 \\
APO10 & Manage Suppliers & 3.5 \\
APO11 & Manage Quantity & 3.5 \\
APO12 & Manage Risks & 3.5 \\
APO13 & Manage Security & 3.3 \\
\hline
\end{tabular}

Based on the table 1, the dimensions in the APO domain are generally at the expected capability level. In detail, the results of the domain analysis show that those that are predictable (level 4), include: manage enterprise architecture, manage innovation, manage portfolios, manage budgets and costs, manage relationships, manage service agreements, manage suppliers, manage quantities and manage risks. Meanwhile, those that have just reached the established process (level 3) are: Manage the IT Management Framework, manage strategy, manage human resources, and manage security.

b. Build acquire, Implement (BAI)

The results obtained from each dimension in the BAI domain were presented in table 2 .

TABLE 2. AVERAGE SCORE OF EACH DIMENSION OF BAI

\begin{tabular}{llc}
\hline Code & Dimension & $\begin{array}{c}\text { Average } \\
\text { Score }\end{array}$ \\
\hline BAI01 & $\begin{array}{l}\text { Manage Programs and } \\
\text { Projects }\end{array}$ & 3.7 \\
BAI02 & $\begin{array}{l}\text { Manage Requirements } \\
\text { Definition }\end{array}$ & 3.3 \\
BAI03 & $\begin{array}{l}\text { Manage Solutions } \\
\text { Identification \& Build } \\
\text { BAI04 }\end{array}$ & $\begin{array}{l}\text { Manage Availability and } \\
\text { Capacity }\end{array}$ \\
BAI05 & $\begin{array}{l}\text { Manage Organizational } \\
\text { Change Enablement }\end{array}$ & 3.5 \\
BAI06 & Manage Changes & 3.5 \\
\hline
\end{tabular}

\begin{tabular}{lll}
\hline BAI07 & $\begin{array}{l}\text { Manage Change Acceptance } \\
\text { and Transitioning }\end{array}$ & 3.4 \\
BAI08 & Manage Knowledge & 3.3 \\
BAI09 & Manage Assets & 3.6 \\
BAI10 & Manage Configuration & 3.6 \\
\hline
\end{tabular}

Based on the table 2, the dimensions in the BAI domain are generally at the expected capability level. In detail, the results of the domain analysis show that those that are predictable (level 4), include: Manage Programs and Projects, Manage Solutions, Manage Organizational Change Enablement, Manage Assets, and Manage Configuration. Meanwhile, those that have just reached the established process (level 3) are: Manage Requirements Definition, Manage Availability and Capacity, Manage Changes, Manage Change Acceptance and Transitioning, and Manage Knowledge.

c. Delivery, Service and Support (DSS)

The results obtained from each dimension in the DSS domain were presented in table 3 .

TABLE 3. AVERAGE SCORE OF EACH DIMENSION OF DSS

\begin{tabular}{llc}
\hline Code & Dimension & $\begin{array}{c}\text { Average } \\
\text { Score }\end{array}$ \\
\hline DSS01 & Manage Operations & 3.8 \\
DSS02 & $\begin{array}{l}\text { Manage Service Requests } \\
\text { and Incidents }\end{array}$ & 3.6 \\
DSS03 & Manage Problems & 3.3 \\
DSS04 & Manage Continuity & 3.5 \\
DSS05 & Manage Security Services & 3.6 \\
DSS06 & Manage Business Process & 3.6 \\
& Controls & \\
\hline
\end{tabular}

Based on the table 3, the dimensions in the DSS domain are generally at the expected capability level. In detail, the results of the domain analysis show that those that are predictable (level 4), include: Manage Operations, Manage Service Requests and Incidents, Manage Continuity, Manage Security Services, and Manage Business Process Controls. Meanwhile, those that have just reached the established process (level 3) is just Manage problems dimension.

d. Monitor, Evaluation and Assess (MEA) The results obtained from each dimension in the MEA domain were presented in table 4. 
TABLE 4. AVERAGE SCORE OF EACH DIMENSION OF MEA

\begin{tabular}{llc}
\hline Code & Dimension & $\begin{array}{c}\text { Average } \\
\text { Score }\end{array}$ \\
\hline MEA01 & $\begin{array}{l}\text { Monitor, Evaluate and } \\
\text { Assess Performance } \\
\text { and Conformance }\end{array}$ & 3.6 \\
MEA02 & $\begin{array}{l}\text { Monitor, Evaluate and } \\
\text { Assess the System of }\end{array}$ & 3.5 \\
Internal Control & \\
MEA03 & $\begin{array}{l}\text { Monitor, Evaluate and } \\
\text { Assess Compliance } \\
\text { with External } \\
\text { Requirements }\end{array}$ \\
\hline
\end{tabular}

Based on the table 4, the dimensions in the MEA domain are generally at the expected capability level. In detail, the results of the domain analysis show that those that are predictable (level 4), include: Monitor, Evaluate and Assess Performance, and Monitor, Evaluate and Assess the System of Internal Control. Meanwhile, those that have just reached the established process (level 3) is just Monitor, Evaluate and Assess Compliance with External Requirements dimension.

e. Evaluate, Direct, Monitor (EDM)

The results obtained from each dimension in the EDM domain were presented in table 5.

TABLE 5. AVERAGE SCORE OF EACH DIMENSION OF EDM

\begin{tabular}{llc}
\hline Code & Dimension & $\begin{array}{c}\text { Average } \\
\text { Score }\end{array}$ \\
\hline EDM01 & $\begin{array}{l}\text { Ensure Governance } \\
\text { Framework Setting and }\end{array}$ & 3.3 \\
& Maintenance & \\
EDM02 & Ensure Benefits Delivery & 3.7 \\
EDM03 & Ensure Risks & 3.5 \\
& Optimization & 3.5 \\
EDM04 & Ensure Resource & \\
EDM05 & Optimization & 3.2 \\
& Ensure Stakeholder & \\
\hline
\end{tabular}

Based on the table 5, the dimensions in the MEA domain are generally at the expected capability level. In detail, the results of the domain analysis show that those that are predictable (level 4), include: Ensure Benefits Delivery; Ensure Risks; and Ensure Resource. Meanwhile, those that have just reached the established process (level 3) are: Ensure Governance Framework Setting and Maintenance; and Ensure Stakeholder Transparency. f. Analysis and Discussion

Based on the results of the above calculations, it can be described in a radar chart along with the dimensions that need to be watched out for in figure 2 .

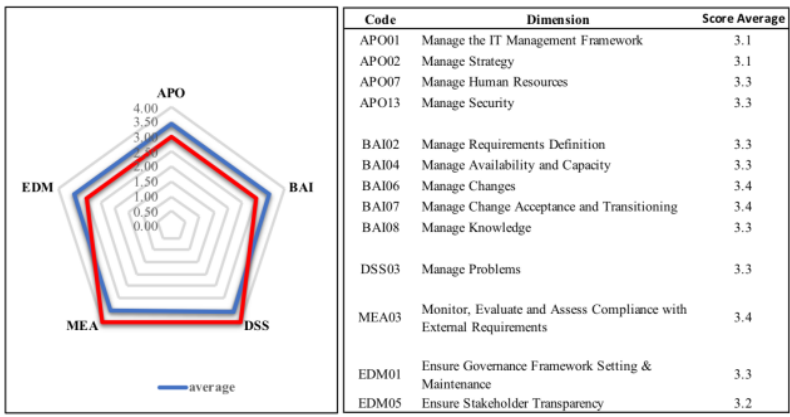

FIGURE 2. RADAR CHART AND DIMENSION OF EVERY DOMAIN THAT NEED MORE ATTENTION

Comparation of this research with previous research of Indonesian Navy Information System Governance [4], can be seen from table 7 , as follows:

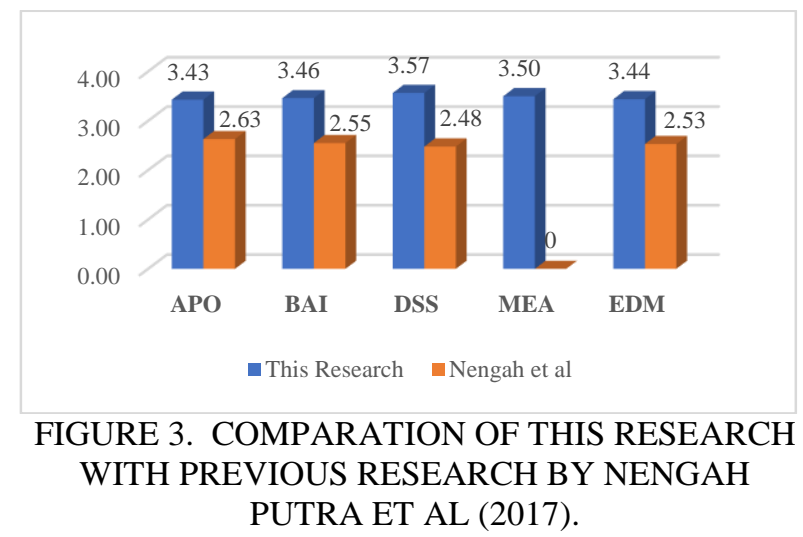

From the comparation we can explain that all the dimension of Indonesian Navy Information system has been grown very well. It shown that the governance of Information System in Indonesian Navy on the right track.

Furthermore, an analysis of the results of interviews with research subjects was carried out. It was found that several implications were made in the form of efforts to improve. The analysis of the results of the interview was carried out using the triangulation method and the results are presented in table 6 : 
TABLE 6. THE RESULTS OF THE INTERVIEW ON REMEDIAL EFFORTS THAT THE INDONESIAN NAVY NEEDS TO DO TO IMPROVE THE IT CAPABILITIES

\begin{tabular}{ll}
\hline Code & \multicolumn{1}{c}{ Improvement } \\
\hline APO01 & $\begin{array}{l}\text { Routinely evaluated the implementation of IT } \\
\text { management in accordance with a well-structured IT } \\
\text { management framework to make it more optimal. }\end{array}$
\end{tabular}

APO02 The IT strategy that has been developed and its implementation needs to be better integrated so that its suitability can be improved

APO07 The placement of IT human resources is optimized according to their areas of expertise based on the Personnel Composition framework that has been compiled based on the competence and work experience of the personnel.

APO13 System security and IT technology are always regulated in SOP, the implementation needs to be improved, especially in the speed of solving security problems.

BAI02 The growing need for IT in the Indonesian Navy needs to be anticipated with closer cooperation with user units.

BAI04 The availability and capacity of IT in the Indonesian Navy which is continuously developed, adjusted to the demands of IT needs and developments, need to be anticipated through collaborations.

Technological changes and the rapidly developing

BAI06 strategic environment need to be anticipated continuously through collaboration with user units and other agencies as well as the development of technical and strategic capabilities of IT personnel in the Indonesian Navy.

BAI07 Conducting dissemination, discussion and workgroups with other units so that the optimization of acceptance of change and transition can be faster and smoother.

Knowledge that has been generated from data and IT

BAI08 systems in the Indonesian Navy and has been managed by archiving, management is improved through dissemination and socialization. Knowledge related to IT needed by the Indonesian Navy is better disseminated in the IT circles of the Navy.

DSS03 Problems related to IT are managed and documented for future best practice.

MEA03 Each complaint is monitored, recorded, evaluated so that its resolution is faster, more precise and precise.

EDM01 IT system governance and maintenance are integrated into the Governance guidelines and evaluated / audited every time to maintain its quality

EDM05 Every interaction and communication carried out with stakeholders needs to be maintained and cross-check is carried out to ensure that transparency and accountability are the main things.

The improvements made in each dimension in each domain if implemented in an integrated manner will accelerate the achievement of a higher level of IT capabilities of the Indonesian Navy.

\section{CONCLUSION}

The conclusion that can be explained is that in general, the attainment of IT capabilities in the Indonesian Navy reaches a good level with 2 domains reaching level 4 and 3 domains reaching level 3 . This is driven by the use of IT in times of an increasingly high pandemic so that IT performance in the Indonesian Navy is forced. just getting better. Besides that, there are 13 dimensions that require treatment to increase its capabilities.

\section{ACKNOWLEDGMENTS}

In accordance with the publishing of this jurnal we would like to take this opportunity to thank you for reviewer's effort and expertise to review my article. Your help enabled us to meet the scheduled time and to maintain the standards of peer-reviewed journals.

\section{REFERENCES}

[1] K. PICH and W. Sardjono, "The Performance of Information System in Facilitating Work Communication by Online-Based Application During Covid Based Application During Covid19 Pandemic Crisis," Airlangga J. Innov. Manag., vol. 1, no. 1, pp. 21-31, 2020, [Online].

Available:

DOI :

10.20473/ajim.v1i1.19398\%0ATHE

[2] F. Veerankutty, T. Ramayah, and N. A. Ali, "Information technology governance on audit technology performance among Malaysian public sector auditors," Soc. Sci., vol. 7, no. 8, 2018, doi: 10.3390/socsci7080124.

[3] M. Axelsen, P. Green, and G. Ridley, "Explaining the information systems auditor role in the public sector financial audit," Int. J. Account. Inf. Syst., vol. 24, pp. 15-31, 2017, doi: 10.1016/j.accinf.2016.12.003.

[4] I. N. Putra, A. Hakim, S. H. Pramono, and H. Tolle, "Adopted COBIT-5 Framework for System Design of Indonesia Navy IS/IT : An Evaluation," 2017. [Online]. Available: http://www.ripublication.com.

[5] A. Aidi, "Program Information System Auditing; Theoritical Approach," Int. J. Sci. Technol. Res. vol. 5, no. 06, pp. 154-158, 2016, [Online]. Available: www.ijstr.org.

[6] "ISACA 2012 COBIT 5: A Business Framework for the Governance and Management of Enterprise IT (USA: ISACA)." 
[7] M. A. Putri, I. Aknuranda, and W. F. Mahmudy, "Maturity Evaluation of Information Technology Governance in PT DEF Using Cobit 5 Framework," 2017. [Online]. Available: www.jitecs.ub.ac.id.

[8] R. Yaniar Sianida, F. Nur Afiana, and R. Wahyudi, "IS Governance Evaluation Using COBIT 5 Framework on the Central Statistics Agency of Banyumas District," J. Comput. Sci. Eng., vol. 1, no. 1, pp. 1-9, Feb. 2020, doi: 10.36596/jcse.v1i1.9.

[9] A. K. Setiawan and J. Fernandes Andry, "IT Governance Evaluation using Cobit 5 Framework on The National Library," J. Sist. Inf., vol. 15, no. 10-17, 2019.

[10] G. Sabatini, D. B. Setyohadi, and W. P. Yohanes Sigit Purnomo, "Information technology governance assessment in Universitas Atma Jaya Yogyakarta using COBIT 5 framework," in International Conference on Electrical Engineering, Computer Science and Informatics (EECSI), 2017, vol. 2017-December, doi: 10.1109/EECSI.2017.8239161.

[11] S. D. Rehatta and A. D. Manuputty, "Measurement of the Maturity Level of IT Governance in Implementing Personnel Management Information System Using the MEA Domain COBIT 5 Framework In Regional Personnel, Education and Training Agency," J. Inf. Syst. Informatics, vol. 1, no. 2, pp. 123-135, 2019, doi: 10.33557/journalisi.v1i2.16. 